\title{
Shattering the myths of private practice
}

\section{Abi Berger}

General Practitioner, London, UK

Correspondence to

Dr Abi Berger,

c/o journal@fsrh.org

Received 6 February 2017

Accepted 10 February 2017

\section{CrossMark}

To cite: Berger A. J Fam Plann Reprod Health Care 2017:43:162.
I have a confession to make. I've gone over to the dark side. I'm now combining National Health Service (NHS) general practice with some private general practitioner work - and I've made some surprising discoveries. I can see 16 patients in the morning and another 16 in the afternoon and get home by $6.15 \mathrm{pm}$. I haven't achieved that in the NHS for at least 10 years. I work alongside really good doctors and the patients are unfailingly polite and grateful - unlike my experience of many patients I have looked after in the NHS. The private patients have access to the clinic in which I work because they get it as a perk of their employment contract - so they're not rich and they come from all walks of life and the vast majority are very down to earth. I get far fewer demands for inappropriate antibiotics than I do from NHS patients - in fact I don't get any 'demands' at all, just requests. And I feel that my opinion is respected. That was myth number one shattered.

The only downside is that I have been experiencing 'survivor guilt' and have definitely not been shouting from the rooftops about what I'm doing. I badly needed some perspective on the NHS, and I'm getting it. With none of the endless tick box data collection and non-evidenced-based 'care planning' required of us in the NHS, I now get to be the kind of doctor I want to be - and haven't been able to be in the NHS for a very long time. I'm still careful about prescribing and only referring to specialists when I think it's necessary - but I no longer have to spend half the consultation apologising for the state the NHS is in. By the same token, I am enjoying the NHS work more - because there I get to see the children and the elderly and the palliative care patients I don't see in the private sector. If you'd asked me a year ago whether I'd ever have seen myself venturing into the private sector the answer would have been a definite 'No'. Ideologically it was never on the cards. But never say never.

I get 15-minute appointments in the private clinic which is utter luxury. And ironically, because patients have complained once too often about me keeping them waiting in the NHS, my NHS manager has now offered me 15-minute appointments in the NHS. Perhaps it's my age, but I haven't been able to stick to 10-minute appointments for years. I give as much to my NHS patients as I always did - but now the appointment system allows me to do what I am already doing and no-one gets upset any more. I still see the same number of patients. It's a win-win.

Myth number two - my income in the private sector is significantly less than it is in the NHS. But I've long since learnt that time is more important than money, and as long as I can pay my bills I'm happy with the drop in salary. Better an 8-hour day than a 12-hour day. Better for me and therefore better for patients. Any day. So I'm smiling more, have more energy to offer, and the NHS will get to keep me and what I perhaps rather arrogantly think of as my 'wealth of experience', for far longer than might have been the case if I'd stayed working just within the NHS. I am restored, enjoying being the best kind of doctor I can be, and am far better value to all the patients I see this way. The perspective looks rosy.

\section{Competing interests None declared.}

Provenance and peer review Commissioned; internally peer reviewed. 